\title{
Effects of Compact Disc-Mediated Instruction and Computer-Based Package on Students' Achievement in Business Studies
}

\author{
Olukemi Josephine Omoniyi \\ Department of office Technology and Management, \\ The Federal Polytechnic, Ado-Ekiti, Nigeria
}

\begin{abstract}
The study investigated the effects of compact discmediated instruction and computer-based package on students achievement in business studies. The study employed the quasi-experimental research of the pre-test, post-test control group design. The sample for the study consisted of 120 students. The findings revealed that the students exposed to computer-based package had better achievement than those exposed to compact disc-mediated instruction $(P<0.05)$. The result indicated that both packages enhanced effective teaching and learning of Business Studies, however, the computer-based package was more effective. It was recommended that both strategies be employed in the teaching and learning of Business Studies. Educational authorities and stakeholders should plan and implement policies that will ensure mass utilization of compact discmedicated instruction and computer-based package in the teaching and learning process in all secondary schools.
\end{abstract}

\section{Introduction}

Technology has become vital in the world's advancement towards a meaningful life, making practical applications and problem-solving easier for man. Advancement in Technology has reduced the world to a global village. Information and knowledge about people and events all around the world are shown live on twenty-four hour basis through the internet.

The joining of computer networks via the internet and the focus on electronic wizardry linked by information super highways, has brought knowledge in its entire splendor within the reach of everyone [1].

This is the era of Information and Communication Technology (ICT) in which the computer plays the central role of information processing and dissemination in making life easier for the entire human race. ICT as defined by [2] is the science and activities of processing, storing and sending information by the use of the computer. Other ICT facilities include television, radio, compact-disc, cinema van, motion pictures.

Today, micro computers are being used by learners for word processing, composition and solving complex mathematical calculations. The advent of instructional technology has changed the world, posing new challenges in societies, professions, business, culture and in particular education. The emergence of computer technology for example has heightened the awareness among educators of the importance of individualization, that is, the quest to find ways of matching individual learner with the appropriate subject matter. All over the world the use of instructional technologies is strongly recognized as an essential part of the curriculum.

In Nigeria, efforts are now being made by various governments at all levels to equip schools with computers under the school connect programme. The application of micro-computers in the classroom is becoming a reality. Educators are becoming more concerned about the educational usefulness and importance of computer-assisted learning and microcomputers effectiveness in the teaching and learning process.

The instructional strategy applied by a teacher is very crucial for meaningful learning to take place. Scholars opined that teachers should approach instructions systematically and purposefully by planning the instruction to form a distinct bridge between what they want to teach and whom they want to teach.

Business Studies is one of the pre-vocational subjects in the junior secondary schools (upper basic level of education). The subject provides orientation and basic skills to start occupation or proceed for further training. It consists of skill and non-skill courses. The study covers the non-skill component (commerce, bookkeeping, office practice) of business studies. The teaching and learning of Business Studies could take the form of compact disc-mediated instruction or computer-based package. A compact disc package makes it possible to record lessons and play back immediately. The package could show different views of a process; 
used to teach skills as components of a lesson; presented over and over again for observation and evaluation, while a computer-based package enables students to learn at their own pace, repeat materials that they found difficult without fear of delaying other students. The package also provides quick feedback of a correct response which is sufficient to motivate students and improve learning.

The researcher observed through her teaching experience that most students do not comprehend Business Studies while many others develop negative attitudes towards the learning of the subject matter due to the teaching method employed in the teaching and learning of the subject. It was observed that Business Studies teachers today, were those trained in social studies and other art related disciplines and not business education major. These teachers therefore could not effectively teach and impart the appropriate skills into students. Most often they apply different meanings and words to the contents of Business Studies leading to distortion of the basic meaning of the subject and poor comprehension of the subject matter by students.

The predominant method of teaching the subject is through the expository or lecture method with the teacher doing most of the talking. Little wonder [2] remarked that Nigeria is faced with educational problem of great magnitude which traditional method of teaching and learning alone cannot achieve. Thus two general questions were raised:

1. What is the achievement of the students exposed to compact disc-mediated instruction in Business Studies?

2. What is the achievement of the students exposed to computer-based package in Business Studies?

To achieve rapid educational technological breakthrough, teachers need to choose the most suiTable media for classroom instruction. The study therefore investigates the effect of compact discmediated instruction and computer-based package on students' achievement in Business Studies.

The purpose of the study was to determine which of the instructional strategies (compact disc-mediated instruction and computer based package) could bring about increased achievement in Business Studies. It also determine which of the strategies could be more effective in the teaching and learning of Business Studies in general and specific aspects of business studies in particular.

\section{Research Hypotheses}

The following hypotheses were generated

$\mathbf{H o}_{1}$ : There is no significant difference between the pre-test achievement mean scores of the experimental and control groups.
Ho2: There is no significant difference between the post-test achievement mean scores of the experimental and control groups

Ho : There is no significant difference in the post-test achievement mean scores on components of Business Studies between the experimental and control groups

$\mathrm{Ho}_{4}$ : There is no significant difference between the pre-test and post-test scores in the experimental and control groups.

\section{Research Method}

The study employed a quasi-experimental research of pre-test, post-test and control group design. The population for the study consisted of all junior secondary class two students in Ekiti State, Nigeria. The sample for the study consisted of 120 students who were selected through proportional stratified random sampling technique while purposive sampling technique was used to select three secondary schools in Ado Local Government Area of Ekiti State, Nigeria. The instrument used for the study was the Business Studies Achievement Test (BSAT) developed by the researcher in collaboration with Business Studies teachers, experts and examiners in Business Studies. The BSAT contained 40 multiple choice items of five options.

The validity of the BSAT was ascertained by experts in business studies, tests and measurement and language studies. Each of them was asked to estimate the face and content validity and their suitability for the target population. Necessary corrections arising from their estimations were effected before the final draft of the instrument. The researcher also made use of Table of specification and test blueprint.

The reliability of the instrument was determined using test-retest method. A correlation coefficient of 0.84 was obtained and found significant at 0.05 level

The research procedure was experimental and took two forms, the pre-treatment stage and the treatment stage. At the pre-treatment stage the BSAT was administered to the 120 students in all the three selected schools to ascertain their cognitive achievement in business studies before the beginning of the experiment. The treatment stage started immediately after the pre-test had been administered and lasted for three weeks based on the school time Table and scheme of work. All the three groups responded to the pretest and post-test.

During the experiments one group received treatment using compact disc mediated instruction, the second group received treatment using computerbased package while the control group were exposed to the normal chalk and talk method.

The computer-based application package was web-based in nature. It was a product of the joint effort of both the researcher and a computer 
programmer making use of the lesson materials prepared for the conventional chalk and talk method. The software was built using a markup language (HTML, Dreamweaver, a scripting language (Php script) a web browser, opera and forge 7.0 sound application package. A comprehensive script for compact disc-mediated instruction was prepared by the researcher with the assistance of video camera man to shoot relevant topics for presenting the instructions to the students.

The data collected were analyzed using appropriate descriptive and inferential statistics. The hypotheses were tested using Analysis of variance and analysis of Covariance. Scheffe post-hoc analysis was carried out where necessary. All hypotheses were tested at 0.05 level of significance.
Descriptive Analysis: What is the achievement of the students exposed to compact disc-mediated instruction and computer-based package in Business Studies?

In order to answer the question, achievement mean scores of students exposed to compact discmediated instruction and computer-based package before and after treatment were computed. The result is presented in Table 1 .

\section{Results}

Table 1. Mean and Standard Deviation of compact disc-mediated instruction and computer-based package in Business Studies

\begin{tabular}{|l|l|l|l|l|l|l|}
\hline & & Pre-test & & Post-test & & \\
\hline $\begin{array}{l}\text { Compact disc- } \\
\text { mediated }\end{array}$ & $\mathrm{N}$ & Mean & SD & Mean & SD & Mean diff \\
\hline Computer-Based & 40 & 38.15 & 10.25 & 58.56 & 10.40 & 20.41 \\
\hline Control & 40 & 38.48 & 11.03 & 59.95 & 9.50 & 21.47 \\
\hline
\end{tabular}

Table1 presents the achievement mean scores of students exposed to compact disc-mediated instruction and computer-based package in Business Studies. The results show that students exposed to compact disc-mediated instruction had pre-test achievement mean score of 38.15 while those in the computer-based and control groups were 38.48 and 34.30 respectively. After the treatment, the post-test mean score of students in the computer-based package group was 59.95 higher than those exposed to compact discmediated instruction with a mean score of 58.56 . The control group had a mean score of 46.63 .

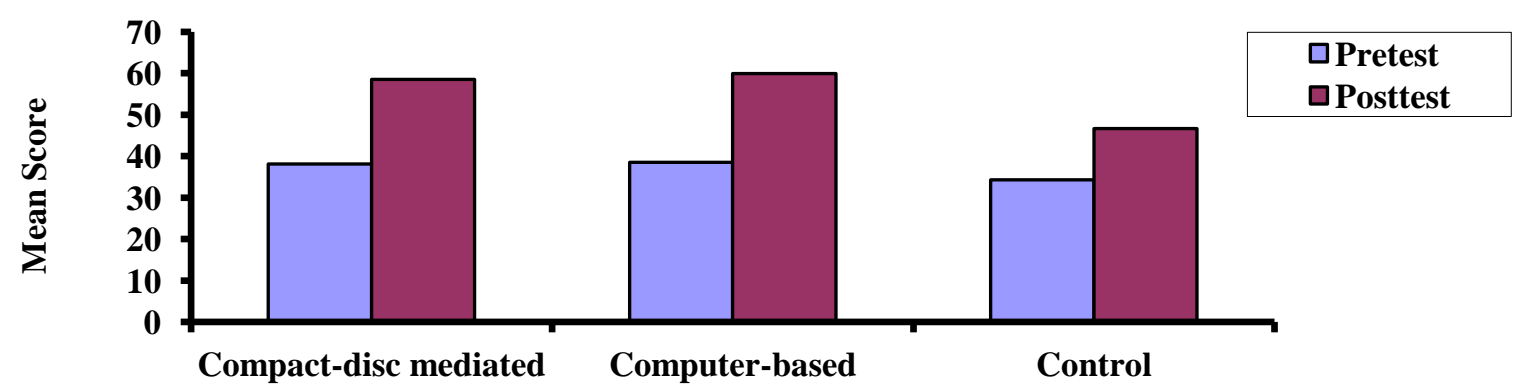

Figure 1: Bar Charts showing the Academic Achievement of Students exposed to Compact-disc mediated and Computer-Based Instructions in Business Studies

Figure 1 shows the academic achievement of students exposed to compact disc-mediated instruction and computer- based package in Business Studies. The results show that students exposed to computer-based package achieved higher (59.95) than compact disc mediated group (58.56). The control group achieved the least (46.63). The mean difference of the three groups were compact disc-mediated (20.41), computerbased (21.47) and control (12.33).

Hypothesis 1: There is no significant difference between the pre-test achievement mean scores of the experimental and control groups.

In order to test the hypothesis, pre-test achievement mean scores of students exposed to different treatments were compared and subjected 
to one-way analysis of Variance (ANOVA) at 0.05 level of significance. The result is presented in
Table 2

Table 2. One-way ANOVA showing the pre-test mean scores of experimental and control groups.

\begin{tabular}{|l|l|l|l|l|l|}
\hline Source & SS & Df & MSS & Fcal & FTable \\
\hline Between Groups & 431.45 & 2 & 215.73 & \multirow{2}{*}{} \\
\cline { 1 - 3 } Within Groups & 11614.39 & 117 & 99.27 & \multirow{2}{*}{2.07} \\
\hline Total & 12045.34 & 119 & & & \\
\hline
\end{tabular}

$\mathrm{P}>0.05$

Table 2 presents the comparison of pre-test mean scores of students in the experimental and control groups. The result shows that Fcal (2.17) is less than FTable (3.07) at 0.05 level of significance. The null hypothesis is not rejected. Therefore, there is no significant difference between the pre-test achievement mean scores of the experimental and control groups. This shows that the three groups are homogeneous.
Hypothesis 2: There is no significant difference between the post-test achievement mean scores of the experimental and control groups.

The post-test achievement mean scores of students in the experimental and control groups were compared and tested for statistical significance using one-way Analysis of variance (ANOVA) at 0.05 level of significance. The result is presented in Table 3.

Table 3. One-way ANOVA of Treatments and post-test mean scores of students in Business Studies.

\begin{tabular}{|c|c|c|c|c|c|}
\hline Source & $\mathrm{SS}$ & df & MSS & Fcal & FTable \\
\hline $\begin{array}{l}\text { Between } \\
\text { Groups }\end{array}$ & 4289.76 & 2 & 2144.88 & \multirow[t]{3}{*}{$21.47 *$} & \multirow[t]{3}{*}{3.07} \\
\hline Within Groups & 11686.76 & 117 & 99.89 & & \\
\hline Total & 15976.52 & 119 & & & \\
\hline
\end{tabular}

$* \mathrm{P}<0.05$

Table 3 shows that Fcal (21.47) is greater than FTable (3.07) at 0.05 level significance. The null hypothesis is rejected. Therefore, there is significant difference between the post-test achievement mean scores of each of the experimental and control groups.

In order to determine the sources of pair-wise significant difference, Scheffe Posthoc test was used. The result shows that there is statistically mean difference between the post-test mean scores of students in the compact disc-mediated and control groups. Similarly, the significance mean difference between the post-test mean scores of students in computer-based and control groups is statistically significant at 0.05 level.
Hypothesis 3: There is no significant difference in the post-test achievement mean scores on components of Business Studies in the experimental and control groups.

In order to test the hypothesis, post-test achievement mean scores of students in the experimental and control groups on each of the components of Business Studies (office practice, commerce, and book-keeping) were compared and subjected to statistical analysis involving Analysis of Covariance (ANCOVA) at 0.05 level of significance. The result is presented in Table 4. 
Table 4. ANCOVA summary of treatments and students' Post-test Achievement mean scores on components of Business Studies

\begin{tabular}{|c|c|c|c|c|c|c|}
\hline $\begin{array}{l}\text { Components of Business } \\
\text { Studies }\end{array}$ & Source & $\mathrm{SS}$ & df & MSS & Fcal & FTable \\
\hline \multirow[t]{6}{*}{ Office Practice } & Corrected Model & 862.72 & 3 & 287.58 & $17.38^{*}$ & 2.68 \\
\hline & Covariate(Pre-test) & 630.51 & 1 & 630.51 & $38.11 *$ & 3.92 \\
\hline & Group & 77.24 & 2 & 38.62 & 2.34 & 3.07 \\
\hline & Error & 1919.36 & 116 & 16.55 & & \\
\hline & Corrected Total & 2782.08 & 119 & & & \\
\hline & Total & 54014.77 & 120 & & & \\
\hline \multirow[t]{6}{*}{ Book-keeping } & Corrected model & 1560.49 & 3 & 520.16 & $44.14 *$ & 2.68 \\
\hline & Covariate(pre-test) & 794.74 & 1 & 794.74 & $67.45^{*}$ & 3.92 \\
\hline & Group & 45.94 & 2 & 22.97 & 1.95 & 3.07 \\
\hline & Error & 1366.88 & 116 & 11.78 & & \\
\hline & Corrected Total & 2927.37 & 119 & & & \\
\hline & Total & 27753.00 & 120 & & & \\
\hline \multirow[t]{6}{*}{ Commerce } & Corrected model & 1799.15 & 3 & 559.72 & $36.34 *$ & 2.68 \\
\hline & Covariate(pre-test) & 850.49 & 1 & 850.49 & $51.54 *$ & 3.92 \\
\hline & Group & 451.64 & 2 & 225.82 & $13.68 *$ & 3.07 \\
\hline & Error & 1914.39 & 116 & 16.50 & & \\
\hline & Corrected Total & 3713.54 & 119 & & & \\
\hline & Total & 51721.54 & 120 & & & \\
\hline
\end{tabular}

Table 4 presents the achievement mean scores of subjects in experimental and control groups. The result reveals that there is significant difference in the post-test achievement mean scores in commerce between the experimental and control groups $(\mathrm{F}=13.68, \mathrm{P}<0.05)$. The hypothesis is therefore rejected. However, the effect of treatment on achievement mean scores of students in office practice $(\mathrm{F}=2.34, \quad \mathrm{P}>0.05)$ and book-keeping $(\mathrm{F}=1.95, \mathrm{P}>0.05)$ is not statistically significant at 0.05 level in each case.

In order to locate the sources of pair-wise significant difference in commerce, Scheffe Posthoc test was used. The result shows that the mean difference between the compact discmediated and control, computer-based and control is statistically significant at 0.05 level in each case. In contrast, there exists no statistical significant difference in the post-achievement mean scores of students exposed to compact disc-mediated instruction and computer-based package at 0.05 level.

Testing the effect of treatment on the adjusted post-test mean scores of students exposed to different treatments, Multiple Classification Analysis (MCA) was used.The result shows that students exposed to computer-based package had the highest adjusted post achievement mean score of $22.38(20.00+2.38)$ in commerce.
This is closely followed by compact discmediated instruction group with an adjusted posttest mean score of $19.83(20.00+(-0.17)$ while the control group obtained the least adjusted post-test mean score of $17.79(20.00+(-2.21)$.

It implies that both computer-based package and compact disc-mediated instructional methods will produce better achievement in commerce. Compact disc-mediated instruction and computer based package could only account for $13 \%$ of the variability in students' achievement in commerce. Thus, there is need to investigate other variables that could account for the remaining variability in students achievements rather than the ones under study.

Hypothesis 4: There is no significant difference between the pre-test and the post-test scores of students in the experimental and control groups. To test the hypothesis, achievement mean scores of students in experimental and control groups were compared and subjected to statistical analysis involving Analysis of Covariance (ANCOVA) at 0.05 level of significance. The result is presented in Table 5. 
Table 5. ANCOVA Summary of Achievement Mean scores of Experimental and Control Groups.

\begin{tabular}{|l|l|l|l|l|l|}
\hline Source & SS & df & MS & Fcal & FTable \\
\hline Corrected Model & 5428.13 & 3 & 1809.34 & $19.90^{*}$ & 2.68 \\
\hline Covariate (pretest) & 1138.36 & 1 & 1138.36 & $12.52^{*}$ & 3.92 \\
\hline Group & 3355.91 & 2 & 1677.96 & $18.45^{*}$ & 3.07 \\
\hline Error & 10548.39 & 116 & 90.93 & & \\
\hline Corrected Total & 15976.52 & 119 & & & \\
\hline
\end{tabular}

$* \mathrm{P}<0.05$

Table 5 shows that Fcal (18.45) is greater than FTable (3.07) at 0.05 level of significance. the null hypothesis is rejected. Therefore, there is significant difference between the pre-test and post-test scores of students in experimental and control groups. This implies that both compact disc-mediated instruction and computer based package are effective instructional methods for enhancing better performance of students in Business Studies.

In an attempt to determine the pair of groups that are significantly different at 0.05 level, Scheffe Posthoc test was used. The results show that the mean difference between control and computerbased group is significant at 0.05 level. Similarly, there is significant mean difference between control and compact disc-mediated groups. There exists no significant difference between the achievement of compact disc-mediated and computer-based groups.

Testing the effect of treatment on the adjusted post-test mean scores of subjects, Multiple Classification Analysis (MCA) was carried out.

The result shows that, with a grand mean of 55.05, students exposed to computer-package had the highest adjusted post-test mean of 60.99 $(55.05+5.94)$. This is closely followed by those exposed to compact disc-mediated instruction with an adjusted post-test mean score of 58.07 $(55.05+3.02)$ while the control group recorded the least adjusted post-test mean score of 47.74 (55.05 $+(-7.31)$.

On the basis of this finding, hypothesis 4 was rejected. There is significant difference between the pre-test and post-test scores of students in the experimental and control groups.

\section{Discussion}

The findings of the study revealed significant difference in the achievement mean scores of students exposed to compact disc-mediated instruction and computer-based package in Business Studies. Considering the performance of the groups, the students exposed to computer-based package performed best, followed by the compact disc-mediated group and the control group.

Although the control group performed better in the post-test than its pre-test, the performance was not as good as the experimental groups due to nonexposure to treatment. However, the result shows that computer-based package could lead to more effective learning than the compact disc-mediated instruction.

This result corroborates other studies which reported that using computer-based package can increase achievement scores by at least one standard deviation [3]. It also agreed with the findings of $[3,4,5,7]$ that compact disc instruction and computer-based package are very relevant for instruction and effective learning.

Therefore, it is important to match the needs of the society by providing better technology support for learning environments [9, 10]. Hence, both compact disc-mediated instruction and computerbased package could be recommended to teachers as effective in the teaching and learning of Business Studies.

The study equally revealed a significant difference between the achievement mean scores of components of Business Studies in the experimental and control groups only in Commerce. The result shows that students exposed to computer-based package had the highest adjusted mean score of 22.38 in Commerce followed by the compact disc-mediated instruction group 19.83, while the control group obtained the least adjusted post-test mean score of 17.79. This implies that computer-based package and compact disc-mediated instructional strategies will produce better achievement in Commerce.

Of equal note is the finding which revealed a significant difference between the pre-test scores of students in experimental and control groups. All the three groups achieved significantly in the posttest scores. The result agreed with the findings of [11] that teaching is a conscious and organized effort that makes learning possible. The students were reinforced by successfully manipulating the environment. The result shows that students must be taught for effective learning to take place. 
This implies that both compact disc-mediated instruction and computer-based package are effective instructional strategies for enhancing better achievement of students in Business Studies. However, the computer-based package has greater potential of enhancing teaching and learning of Business Studies in Secondary Schools.

\section{Conclusion and Recommendations}

The findings of the study led to the conclusion that the two strategies are effective in the teaching and learning of Business Studies. However, the computer -based package was more effective. With the level of dynamism in the educational and business world, there is need for the $21^{\text {st }}$ century school to focus on empowering its students to acquire the basic business studies skill through the use of compact disc-medicated and computer-based package as powerful learning tools.

It was recommended that the use of compact disc-mediated instruction and computer-based package should be encouraged in the teaching and learning of Business Studies. The government should provide computers, compact discs and other instructional materials in schools to aid the teaching of Business Studies. It is recommended that business teachers should be encouraged to attend workshops and seminars to update their knowledge and enhance better strategies in the teaching of the subject.

Instructional material developers and facilitators should be encouraged to design, develop and integrate the two packages into their delivery system.

Lastly, Business Studies experts should be resourceful enough to design and produce compact disc-mediated and computer based packages to enhance delivery of instructions.

\section{References}

[1] Hackbarth, S. (1996). The educational technology handbook.A comprehensive guide. New Jersey. Educational Technology publication

[2] Badru, F.M (2002). Using information and communication technology to pursue the goals of primary education. A paper presented at the national conference of Nigeria association for educational media and technology (NAEMT).

[3] Schacter, J. (1999). The impact of education technology on student achievement: what the most current research has to say. Santa Monica, CA: Exchange on Education Technology.

[4] Connolly, T., MacArthur, E., Stansfield, M. \&McLellan, E. (2007). A quasi - experimental study of three online learning courses in computing.Computers \& Education 49 (2), 345- 359.

[5] Unwin, D. and McAleese, R. (1988). The encyclopedia of educational media communication and technology. (2nded). New York: Greenwood Press.

[6] Wright, E.E (1993). Making the multimedia decision strategy for success in instructional delivery system. Winter $15-22$.

[7] Adeosun, O. V (2002). Relative effects of three multimedia packages on students achievement and retention in social studies. Unpublished Ph.D Thesis, University of Ado-Ekiti.

[8] Bada, T.A (2004). The effects of locally produced interactive instructional package and demographic variables on the acquisition of textile design skills of junior secondary school students. Unpublished Ph.D Thesis, ObafemiAwolowo University, Ile-Ife.

[9] Osokoya, I.O. (2006). A path-analytic study of teaching quality variables as determinants of achievement in secondary creative design. Journal of business management and training, 7(1), $80-86$.

[10] Schank, R.C. and Cleary, C. (1995). Engines for education. Hillsdale, NJ: Lawrence Eribaum Associates.

[11] Schelechty, P.C. (1997). Inventing better schools: an action Plan for educational reform. San Francisco, CA: Jossey-Boss Inc.

[12] Tiemann, P.W, and Markle, S.M. (2007). Programmed instruction Microsoft (B) student 2008 (DVD). Redmond, W.A: Microsoft corporation.

[13] Laferriere, T, Breuleux, A. and Bracewell,R. (1999). Benefits of using information and communication technologies (ICT) for teaching and learning in $\mathrm{K}-$ 12/13 classrooms: School Net Programme Industry. Canada. 